\title{
Use of 16S rRNA Oligonucleotide Probes to Monitor Sulfate-Reducing Bacteria, Archaea and Fe(II) Oxidizer in the Okinawa Trough Basin
}

\author{
Li-Min Chen $^{1}$ and Jau-Der Chen ${ }^{1, *}$ \\ (Manuscript received 14 November 2000, in final form 15 January 2001)
}

\begin{abstract}
The microbial world of the deep subsurface environment located off the east coast of Taiwan, in the most southern part of the so-called Okinawa Trough, was studied using specific 16S rRNA oligonucleotides to target selected reducing and oxidizing bacteria. The sampling area consists of a cluster of volcanoes under an anoxic sea bottom. Sulfate-reducing bacteria were found to be dominant, by membrane hybridization with an SRB804 probe. Archaea was the second major group and was detected using an ARC915 probe. Very few nitrate-dependent ferrous iron oxidizers were identified in this extremely anoxygenic environment. Since adaptation to a habitat by reducing or oxidizing bacteria depend upon the redox potential of an environment, the sulfate-reducing bacteria and Archaea found suggest that the collected sediments offer extremely anoxygenic conditions. Results further indicated the absence of oxygen at the hydrothermal vents of the volcano in the area investigated which shows that the volcano is dormant.
\end{abstract}

(Key words: Archaea, Fe(II) Oxidizer, Okinawa Trough, SRB)

\section{INTRODUCTION}

The sediment of the ocean bottom was thought lifeless until an international ocean drilling program (ODP) was carried out by an ocean research ship, the JOIDES Resolution. In Leg 180 of the ship's schedule, the abundance of microbial life was discovered using a cultureindependent method (Taylor et al. 2000). This result initiated an interested issue in studies the unknown life that had been present in the deep-sea biosphere.

Microorganisms from extreme environments under the sea bottom, such as hydrothermal vent ecosystems (Karl et al. 1980) and black smokers (Jannasch and Mottl 1985), continue to provide surprises about life's extremities (Stetter 1995). The area located to the north-east of Taiwan, the so-called the most southem part of Okinawa Trough (SPOT) has been found to be

\footnotetext{
${ }^{1}$ Department of Aquaculture, National Taiwan Ocean University, Keelung, Taiwan, ROC

${ }^{*}$ Corresponding author address: Dr. Jau-Der Chen, Department of Aquaculture, National Taiwan Ocean University, 2, Pei-Ning Rd., Keelung, Taiwan, ROC; E-mail: B0129@mail.ntou.edu.tw
} 
scattered with a lot of black smokers and possible hydrothermal vents, both derived from the activities of volcano under the sea bottom. This environment is suitable for studying the geological formation and the extent of deep-sea biosphere.

Explorations of the deep subsurface geological formations for microbial life were initiated in the late 1980s (Atlas and Bartha 1998). Until early 1990, molecular analyses were used to study nonculturable microorganisms in nature (Sayler and Layton 1990). Numerous gene probes for diagnostic sequences have been developed so that selected species, genera, or higher level taxonomic groups can be detected (Amann et al. 1995; Woese et al. 1983). Though a method for identification of uncultured bacteria based on 16S rRNA sequences was argued in the early 1990s (Pace 1996; Amann et al. 1994; Stahl 1993), it was not finally accepted until late 1990s by investigators in the field of microbial ecological communities. The applications of oligonucleotides hybridization probes and polymerase chain reaction (PCR) primers have become widespread in the fields of microbial ecology and environmental microbiology (Amann et al. 1995; Atlas et al. 1992; Ward et al. 1992; Holben and Tiedje 1988; Holben et al. 1988). Alm et al. (1996) designed the oligonucleotide probe database (OPD) to standardize the oligonucleotide probe nomenclature according to the descriptions of probe applications that were abundant in the literature. In general, oligonucleotide probes of 18-20 nucleotides were commonly used in hybridization and could be easily designed from the Ribosomal Database Project (RDP) (Maidak et al. 1999, 1996; Baranov et al. 1999).

The main goal of cruise number 586 by Ocean Researcher I (OR586) was to collect the sediments from the SPOT which consists of a cluster of volcanoes under the sea bottom. The collected sediments from this area are useful for the study in geology, paleontology, and ancient climates, among others. The active or dormant volcanoes under the sea bottom off the eastern coast of Taiwan are also surveyed. Since the understanding of microbial life in the deep-sea biosphere of the SPOT was limited, an approach using culture-independent techniques was proposed by Taiwan's ODP group. Thus, another aim of this leg of OR586's voyage was to initiate a study of the microbial life of deep-sea biosphere in addition to the conventional geological research. RNA technology, including nucleic acid extraction from sediment (Purdy et al. 1996), quantitative hybridization (Polz and Cavanaugh 1997), and the technique of PCR, were applied in this study. Since microorganisms' adaptation in an extremely anoxygenic conditions, such as next to volcano under sea bottom, depends upon the redox potential of the environment, two reducing and one oxidizing microorganisms were selected as microbial indicators to reflect this situation. This paper describes the primary results of OR586 drilling related to microorganisms.

\section{MATERIALS AND METHODS}

\subsection{Sites of Sampling}

On 24 and 25, June 2000 OR586 was located at investigated the area between north latitudes $24^{\circ} 46.99^{\prime}$ and $24^{\circ} 55.02^{\prime}$ and east longitudes $122^{\circ} 30.00^{\prime}$ and $122^{\circ} 32.44^{\prime}$. Sampling station locations are listed in Table 1. Samples of deep seawater from 20 meter above sea bottom were collected using CTD (abbreviation for chromatography, temperature, and density) 
Table 1. List of general background of sampling sites by OR586.

\begin{tabular}{|c|c|c|c|c|c|c|}
\hline $\begin{array}{l}\text { Drilling } \\
\text { Station }\end{array}$ & $\begin{array}{c}\text { Date } \\
\text { (year/month/day) }\end{array}$ & Type of core & $\begin{array}{c}\text { Depth of sea water } \\
\text { mbsf* }\end{array}$ & $\begin{array}{c}\text { Depth of sampling } \\
\text { mbsf }\end{array}$ & Latitude & Longitude \\
\hline CTD-station 1 & 2000.6 .24 & CID & 1289 & 1260 (water) & N $24^{\circ} 55.02^{\prime}$ & E $122^{\circ} 29.96^{\prime}$ \\
\hline CTD-station 2 & 2000.6 .24 & CTD & 1194 & 1180 (water) & N $24^{\circ} 54.12^{\prime}$ & E $122^{\circ} 32.44^{\prime}$ \\
\hline CTD-station 3 & 2000.6 .24 & CTD & 1280 & 1260 (water) & $\mathrm{N} 24^{\circ} 48.20^{\prime}$ & E $122^{\circ} 30.16^{\prime}$ \\
\hline BC-station 2 & 2000.6 .25 & Box core & 1201 & 1203 (sediment) & N $24^{\circ} 54.07^{\prime}$ & E $122^{\circ} 32.09^{\prime}$ \\
\hline BC-station 3 & 2000.6 .25 & Box core & 1271 & 1273 (sediment) & $\mathrm{N} 24^{\circ} 47.99^{\prime}$ & E $122^{\circ} 30.00^{\prime}$ \\
\hline BC-station 4 & 2000.6 .25 & Box core & 1229 & 1270 (sediment) & $\mathrm{N} 24^{\circ} 47.01^{\prime}$ & E $122^{\circ} 30.00^{\prime}$ \\
\hline BC-station 5 & 2000.6 .25 & Box core & 1236 & 1280 (sediment) & $\mathrm{N} 24^{\circ} 47.01^{\prime}$ & E $122^{\circ} 30.97^{\prime}$ \\
\hline PC-station 3 & 2000.6 .25 & Piston core & 1272 & 1274 (sediment) & $\mathrm{N} 24^{\circ} 48.0 !^{\prime}$ & E $122^{\circ} 30.03^{\prime}$ \\
\hline PC-station 4 & 2000.6 .25 & Piston core & 1227 & 1265 (sediment) & $\mathrm{N} 24^{\circ} 46.99^{\prime}$ & E $122^{\circ} 30.01^{\prime}$ \\
\hline PC-station A1 & 2000.6 .25 & Piston core & 1485 & 1569 (sediment) & $\mathrm{N} 24^{\circ} 52.01^{\prime}$ & E $122^{\circ} 29.98^{\prime}$ \\
\hline
\end{tabular}

*meter below sea surface

core for collection at the first three sites. Anoxic seawater sediments were collected using the boxed core and piston core equipment on the board of OR586.

\subsection{Storage of Samples}

When each CTD core was lifted from the sea bottom and settled aboard ship, a water sample (12 liters) was immediately filtered under vacuum by passing through a sterile $0.2-\mu \mathrm{m}$ filter membrane. This membrane was inserted into a sterile vial and stored in a tank pre-filled with liquid nitrogen. Sediments collected as boxed cores were gently removed from the bottom of the box. The outside sediment was gently removed using a sterile scalpel. The middle part of each sediment sample was carefully collected and dropped into a sterile vial for freezing in liquid nitrogen. 4.5 -m-long piston cores were lifted from the sea, laid aboard the ship and then separated into three sections. The 2 to 3 -cm-thick sediments located on the split junction were carefully scraped away with a sterile scalpel. Sediments below it were retrieved into a sterile vial, which was soon immersed in liquid nitrogen. All the vials were transported back to the laboratory and maintained at $-80^{\circ} \mathrm{C}$ until processed.

\subsection{RNA Preparation}

The method of rapid rRNA extraction from sediments followed was that designed by Purdy et al. (1996). The frozen vials were thawed at room temperature for $20 \mathrm{~min}$ and the sediments $(10 \mathrm{~g})$ aliquoted $(0.5 \mathrm{~g})$ into twenty $2-\mu \mathrm{l}$ screw-cap tubes, each with $0.5 \mathrm{~g}$ of $0.1-\mathrm{mm}$ diameter glass beads pre-baked at $260^{\circ} \mathrm{C}$. $0.7 \mathrm{ml}$ of $120 \mathrm{mM}$ sodium phosphate buffer $(\mathrm{pH} 8$. 0 ) plus $1 \%$ acid-washed polyvinyl-polypyrrolidone (Holben et al. 1988), Tris-equilibrated phenol $(0.5 \mathrm{ml}, \mathrm{pH} 8.0)$, and $20 \%$ sodium dodecyl sulfate $(50 \mu \mathrm{l})$ were added to each tube. The samples were bead beaten (Mini-BeadBeater Type BX-4 Cell Disrupter, Biospec Products, Inc., Bartlesville, OK, USA) three times at $4600 \mathrm{rpm}$ for 30 seconds with 30 seconds on ice in between bead beatings. They were then centrifuged at 13,000 X g for $5 \mathrm{~min}$, and the superna- 
tants pooled and stored on ice. The residual nucleic acid in the pellet was re-suspended in 0.7 $\mathrm{ml}$ of $120 \mathrm{mM}$ sodium phosphate ( $\mathrm{pH} 8.0$ ), bead beaten at $4600 \mathrm{rpm}$ for 30 seconds, and then centrifuged again. The supernatants from both the first and second extractions were pooled and loaded onto a prepared hydroxyapatite (HTP; Bio-Gel; Bio-Rad Laboratories Ltd., Hercules, CA, USA) spin column. An HTP spin-column was used to purify RNA as described by Purdy et al. (1996). The proteins binding to the HTP were removed by washing with $0.5 \mathrm{ml}$ of 120 $\mathrm{mM}$ sodium phosphate $(\mathrm{pH} 7.2)$ and followed by $0.7 \mathrm{ml}$ of $170 \mathrm{mM}$ potassium phosphate $(\mathrm{pH}$ 7.2) once at $5000 \mathrm{rpm}$ for $5 \mathrm{~min}$. Then, the RNA was eluted into three sterile 1.5-ml.Eppendorf tubes each containing $0.7 \mathrm{ml}$ of $300 \mathrm{mM}$ potassium phosphate (pH 7.2). Samples ( $3 \mu \mathrm{l})$ that contained RNA from each tube were immediately determined by running $1.0 \%$ agarose gel electrophoresis under MOPS buffer (Sambrook et al. 1989). The RNA eluates were diluted with $0.7 \mathrm{ml}$ of sterile deionized water and then reloaded onto a new HTP spin column in 0.7$\mathrm{ml}$ aliquots. The column was then washed once with $0.5 \mathrm{ml}$ of $120 \mathrm{mM}$ sodium phosphate $(\mathrm{pH}$ 7.2) and then the RNA was eluted with $0.4 \mathrm{ml}$ of $300 \mathrm{mM}$ potassium phosphate (pH 7.2). The eluent was desalted using a 2.5-ml Sephadex G-75 spin column (Moran et al. 1993), and the nucleic acid was precipitated with 2.5 volumes of ethanol. The mass of RNA was determined by spectrophotometer analysis. The nucleic acids of water samples were extracted directly by giving smashed $0.2-\mu \mathrm{m}$ filter membranes the same treatment as the sediment samples.

\subsection{Filter Hybridization and RNA Analysis}

Heat-denatured RNA (in $400 \mu 1 \mathrm{TE}$ buffer) was filtered by passing through a 48-well slot $(1.0 \times 4.0 \mathrm{~mm})$ of the convertible filtration manifold system (Gibco BRL Products, Life Technologies, Taipei, Taiwan) by vacuum to bind onto a positively charged nylon membrane. The nucleic acids were cross-linked on the membrane by heating at $120^{\circ} \mathrm{C}$ for $30 \mathrm{~min}$. The $16 \mathrm{~S}$ rRNA probes used in this study (see Table 2) comprised a universal probe for all organisms, a specific probe for Desulfobacter group, a domain-specific probe for Archaea, a specific probe for nitrate-dependent ferrous iron oxidizers and a specific probe for Vibrio anguillarum. All these probes were artificially synthesized by a local commercial supplier (Sheng-Kang Inc., Taipei, Taiwan) and end-labeled with $\left[\gamma^{32} \mathrm{P}\right] \mathrm{ATP}$ using polynucleotide kinase. Labeled probes were incubated with dot blots in hybridization buffer as suggested by the manufacturer (Roche Diagnostics GmbH, Mannheim, Germany). The final wash temperature corresponded to the temperature of dissociation (Td) previously determined for each probe, with the exception of the all-organisms (universal) probe for which a $50^{\circ} \mathrm{C}$ wash temperature was used in this study. For each sample, duplicate slots on the membrane were made. One slot for each sample was cut and dropped into a vial that contained cocktail for monitoring the radioactivity of the hybridized probe using a $\beta$-scintillation counter (Beckman LS 5000TA; Beckman Instruments, Inc., Fullerton, CA, USA). The amount of radioactivity determined by the hybridized radioactive labeled probe represents the RNA abundance of each detected organism. The other slot for each sample was mounted on X-film to develop an image to show the presence of the RNA bound by the specific probe.

\subsection{DAPI Enumeration}

Sediments $(3 \mu \mathrm{g}$ ) were suspended in $27 \mathrm{ml} 0.15 \mathrm{M} \mathrm{NaCl}$ with $3 \mathrm{~g}$ glass beads in 160 -ml 
Table 2. Oligonucleotide probes chosen from RDP that complement to specific 16S rRNA of selected bacteria.

\begin{tabular}{|c|c|c|c|c|c|}
\hline Probe name & OPD nomenclature* & Target group & Probe sequence $5^{\prime} \rightarrow 3^{\prime}$ & $\operatorname{Td}\left({ }^{\circ} \mathrm{C}\right)$ & References \\
\hline Universal 1392 & S-*-Univ-1392-a-A-15 & All organisms & ACGGGCGGTGTGT(A/G)C & 50 & Stahl et al. $1988 ;$ Olsen et al. 1986 \\
\hline SRB 804 & S-*-Dsb-0804-a-A-18 & $\begin{array}{l}\text { Desulfobacter } \\
\text { Desulfobacterium } \\
\text { Desulfosarcina variabilis } \\
\text { Desulfococcus multivorans } \\
\text { Desulfobotulus sapovorans }\end{array}$ & CAACGTTTACTGCGTGGA & 46 & Devereux et al. 1992 \\
\hline ARC 915 & S-D-Arch-0915-a-A-20 & Archaea & GTGCTCCCCCGCCAATTCCT & 56 & Amann et al. 1990; 1995 \\
\hline BRG-I 829 & & $\mathrm{Fe}(\mathrm{II})$ oxidizer & AAAGTGAATTCCCAACAAC & 46 & Straub and Buchholz-Cleven 1998 \\
\hline $\mathrm{VaV3}$ & S-S-V.ang-0454-a-A-24 & Vibrio anguillarum & TGATGCTGCTATTAACAACACCA & 50 & Martinez-Picado et al. 1994; Dorsch et al. 1992 \\
\hline
\end{tabular}

*Standardization of oligonucleotide probe nomenclature based on the designation by Alm et al. (1996) 
acid-washed bottles. The bottles were shaken for 30 seconds and allowed to stand 10 seconds. This was repeated three times. Samples were set aside for 5 minutes after shaking. The upper supernatants $(0.5 \mathrm{ml})$ were transferred into a fresh bottle and diluted 500 -fold with distilled water. Part of this diluted sample $(50 \mathrm{ml})$ was filtered by passing through a $47-\mathrm{mm}$-diameter, 8- $\mu \mathrm{m}$ pore-size membrane under $-0.05 \mathrm{MPa}$ vacuum and subsequently passing through another 3- $\mu \mathrm{m}$ pore-size membrane. To part of this filtrate $(19 \mathrm{ml})$ was added $1-\mathrm{ml}$ formaldehyde $(37 \%)$ in a separate beaker. A small amount of the $0.5-\mathrm{ml}$ filtrates were immediately filtered by passing through a 25 -mm glass microfiltration unit (Corning Costar, Cambridge, MA, USA), which consisted of a $0.2-\mu \mathrm{m}$ polycarbonate black membrane filter (Nuclepore Track-Etch membrane, lot \# 223005, Poretics, USA) overlain on a 24-mm glass microfibre filter paper (Whatman GF/C, Cat No. 1822 024). After filtration, the membrane was stained with $0.5-\mathrm{ml}$ DAPI (4', 6-diamidino-2-phenylindole, $1 \mathrm{mg} / \mathrm{ml}$ ) for 10 minutes. The stained solution was subsequently removed by vacuum. The stained membrane was air-dried for 2 minutes and then transferred onto a clean glass microscope slide. It was then wetted with a drop of low fluorescing immersion oil and a cover-glass was applied. The most-probable-number (MPN) was enumerated by averaging counts of 20 view-fields under epifluorescent microscopy, according to the equation $\mathrm{a}=(\mathrm{N} * \mathrm{~B}) /\left(\mathrm{M}^{*} \mathrm{~V}^{*} \mathrm{D} * \mathrm{E}\right)$, where $\mathrm{a}=$ cells $/ \mathrm{cm}^{3}$ or $\mathrm{g} ; \mathrm{N}=$ averages of numbers of bacteria observed under epifluorescent microscopy; $\mathrm{B}=$ area of membrane, 201. $06 \mathrm{~mm}^{2} ; \mathrm{M}=$ area of view-fields, $0.0154 \mathrm{~mm}^{2} ; \mathrm{V}=$ amounts of filtrate; $\mathrm{D}=$ folds of dilution; $\mathrm{E}=$ amount of original samples (Hobbie et al. 1977).

\section{RESULTS}

Microbial counts were directly enumerated under a microscope after staining with DAPI. The averaged counts represent the total biomass of samples in a defined unit. This MPN value equals the result of radioactivity counts determined using universal 1392 probe. The radioactivity counts from universal 1392 probe hybridization were presumed to be $100 \%$. The radioactivity counts from each hybridized specific probe that used a $\beta$-scintillation counter reflect the amounts of each examined microorganism present in the sample. The percentage of the radioactivity count of each hybridized specific probe in comparison with that of universal 1392 probe represents the proportion of the total biomass for each examined microorganism. Therefore, the MPN counts for each microorganism were estimated by the conversion of MPN counts of total biomass times the percentage of radioactivity counts for each specific probe. The parallel samples hybridized by specific probes developed into an image and were shown on X-film. Naturally, the targeted microorganisms that could not be hybridized by these specific probes to develop into an image on X-film were defined as absent and the data discarded. The results are listed in Table 3 and the image of each hybridized sample shown in Fig 1.

Microorganisms in deep seawater below 1200 meters were detected in very low quantity. Average of 10 cells per $100-\mathrm{ml}$ deep seawater could be counted by DAPI stain. None of the sulfate-reducing bacteria, Archaea, or ferrous-oxidizer bacteria could be detected using the selected 16S rRNA specific probes.

The abundance of microorganisms living in the sea-bottom sediments could be directly enumerated under a microscope. An average of more than $10^{5-6}$ cells per gram of sediment was 
Table 3. MPN of samples that detected by specific $16 \mathrm{~S}$ rRNA targeted probes.

\begin{tabular}{|c|c|c|c|c|c|c|}
\hline Site of sampling & MPN & Universal 1392 & SRB 804 & ARC 915 & BRG-I 829 & $\mathrm{VaV3}$ \\
\hline \multirow[t]{2}{*}{ CTD-station 1} & & $100 \%$ & & & & \\
\hline & $12^{\mathrm{a}}$ & $(280)^{c}$ & ND & ND & ND & ND \\
\hline \multirow[t]{2}{*}{ CTD-staion 2} & & $100 \%$ & & & & \\
\hline & $7^{a}$ & $(316)^{c}$ & ND & ND & ND & ND \\
\hline \multirow[t]{2}{*}{ CTD-station 3} & & $100 \%$ & & & & \\
\hline & $11^{a}$ & $(196)^{c}$ & ND & ND & ND & ND \\
\hline \multirow[t]{2}{*}{ BC-station 2} & & $100 \%$ & $23.04 \%$ & $23.98 \%$ & $1.08 \%$ & \\
\hline & $4.78 \times 10^{5} \quad b$ & $(7013)^{c}$ & $1.10 \times 10^{5}$ & $1.14 \times 10^{5}$ & $5.17 \times 10^{3}$ & ND \\
\hline \multirow[t]{2}{*}{ BC-station 3} & & $100 \%$ & $26.69 \%$ & $24.48 \%$ & $3.07 \%$ & \\
\hline & $4.56 \times 10^{6} \quad b$ & $(6509)^{c}$ & $1.21 \times 10^{6}$ & $1.11 \times 10^{6}$ & $1.40 \times 10^{5}$ & ND \\
\hline \multirow[t]{2}{*}{ BC-station 4} & & $100 \%$ & $24.62 \%$ & $22.10 \%$ & $4.64 \%$ & \\
\hline & $2.08 \times 10^{6} b$ & $(7177)^{c}$ & $5.14 \times 10^{5}$ & $4.61 \times 10^{5}$ & $9.69 \times 10^{4}$ & ND \\
\hline \multirow[t]{2}{*}{ BC-station 5} & & $100 \%$ & $21.71 \%$ & $14.18 \%$ & $2.49 \%$ & \\
\hline & $4.67 \times 10^{5} \quad b$ & $(7866)^{c}$ & $1.01 \times 10^{5}$ & $6.63 \times 10^{4}$ & $1.16 \times 10^{4}$ & ND \\
\hline \multirow[t]{2}{*}{ PC-station 3} & & $100 \%$ & $22.07 \%$ & $19.25 \%$ & $2.24 \%$ & \\
\hline & $2.43 \times 10^{5}$ & $(8136)^{c}$ & $5.37 \times 10^{4}$ & $4.69 \times 10^{4}$ & $5.45 \times 10^{3}$ & ND \\
\hline \multirow[t]{2}{*}{ PC-station 4} & & $100 \%$ & $27.49 \%$ & $23.53 \%$ & $1.94 \%$ & \\
\hline & $2.06 \times 10^{5}$ & $(6392)^{c}$ & $5.68 \times 10^{4}$ & $4.86 \times 10^{4}$ & $4.01 \times 10^{3}$ & ND \\
\hline \multirow[t]{2}{*}{ PC-station A1 } & & $100 \%$ & $20.16 \%$ & $17.82 \%$ & $3.78 \%$ & \\
\hline & $3.35 \times 10^{5} \quad b$ & $(7891)^{\mathrm{c}}$ & $6.75 \times 10^{4}$ & $5.97 \times 10^{4}$ & $1.26 \times 10^{4}$ & ND \\
\hline
\end{tabular}

a: cells / $100 \mathrm{ml}$ of seawater b: cells / $\mathrm{g}$ of sediments

c: Number within the parenthesis is a unit of $\mathrm{cpm}$.

ND: Image that could not be developed on X-film was defined as "not detected". 


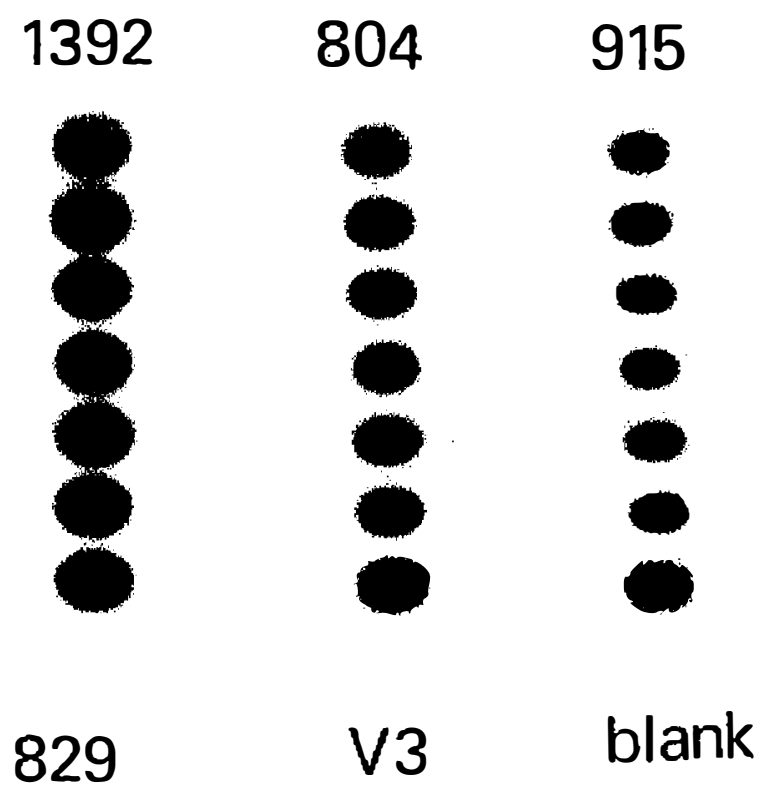

Fig. 1. Hybridization of membrane bound RNA by specific oligonucleotide probes. Numbers above each autoradiograph indicate the hybridization probes used. 1392: universal 1392, 804: SRB804, 915: ARC915, 829, BRG-I 829, V3: VaV3. In addition, TE buffer that filtered through membrane was used as blank control without hybridized by isotope labeled probe. Samples of sediments that collected from boxed cores and piston cores were listed in order according to the sites of sampling. They are in order from top to bottom: BC-station 2, BC-station 3, BC-station 4, BCstation 5, PC-station 3, PC-station 4 and PC-station A1. Ten $\mu \mathrm{g}$ of RNA were used for hybridization with 1392,804 , and 915 probes. The remaining $3 \mu \mathrm{g}$-RNAs were aliquoted into 2 parts for hybridization with 829 and V3 probe. Membrane that bound by RNA was exposed on Xfilm for 18 days. 
(a)

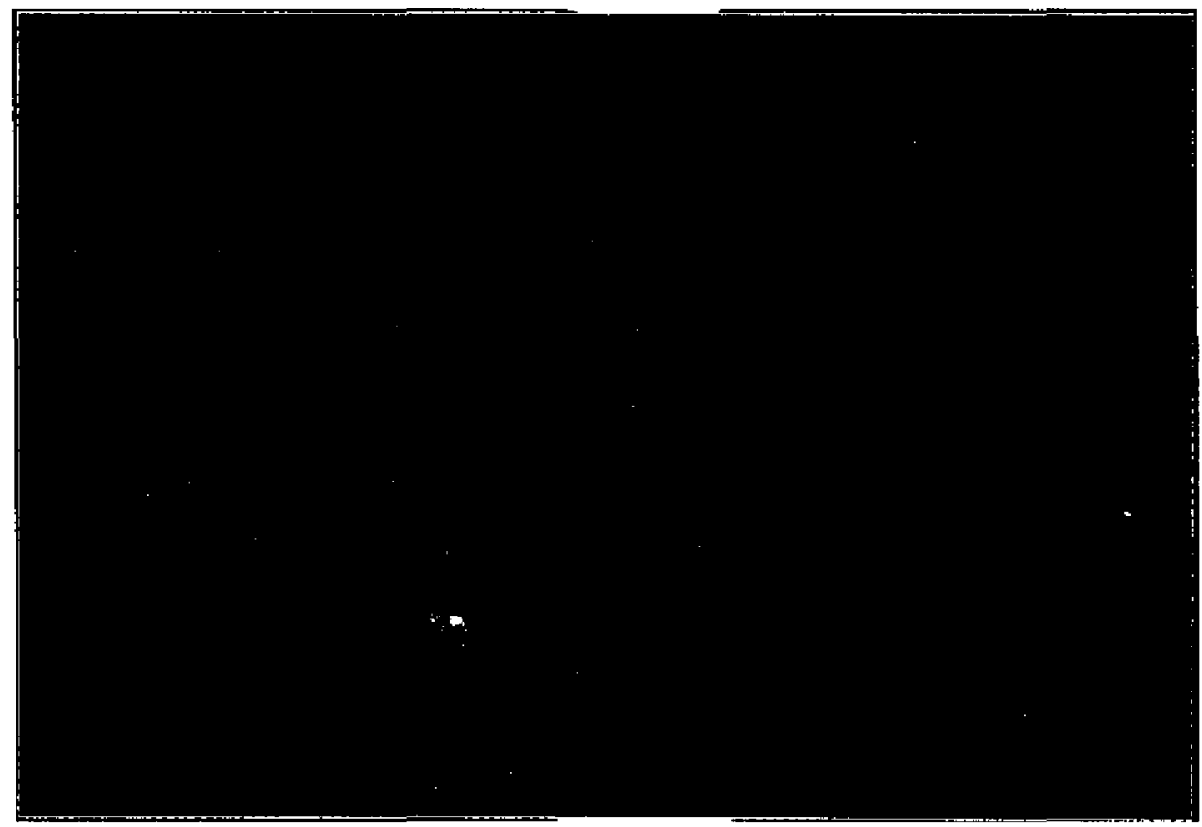

(b)

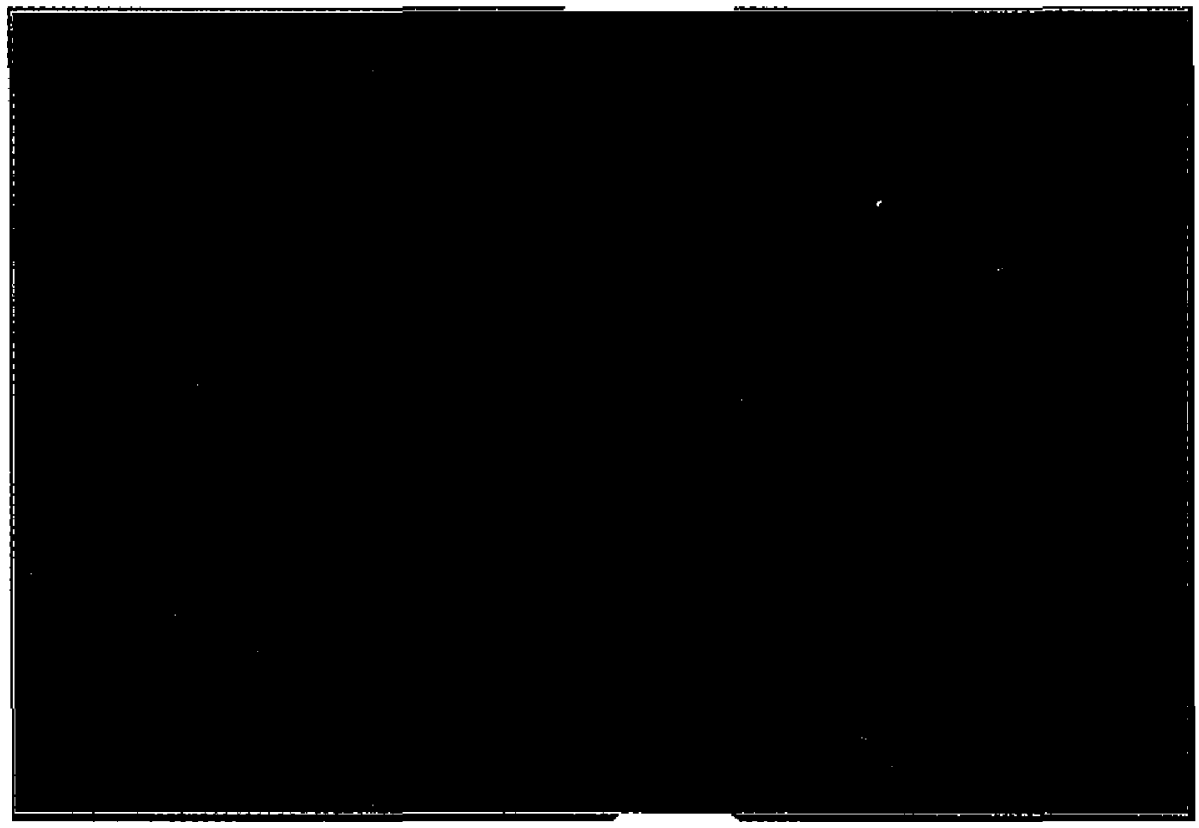

Fig. 2. DAPI-stained cells in sediments from piston core collection. Maginification, 1000 folds. A: Short rod form of bacteria. 1.5 to $2 \mu \mathrm{m}$ in length. B: Long rod bacterium and estimated $10 \mu \mathrm{m}$ in length. The black bar represents $10 \mu \mathrm{m}$. 
counted using DAPI staining. The morphology of the predominant population was short rods (see Fig. 2). No cocci or filamentous bacteria were observed under epifluorescent microscopy.

Sulfate-reducing bacteria, as hybridized by the SRB 804 probe, were the dominant group in all examined samples, and represented approximate $1 / 4$ to $1 / 5$ of total MPN counts. The group of Archaea hybridized by the ARC915 probe was found in all sediments in the same situation as the dominant SRB group. In general, Archaea groups occupied less than $25 \%$ of total DAPI-scored microorganisms. Both SRB and Archaea accounted for about 50\% of biomass in the examined samples, according to the MPN values.

Ferrous iron oxidizers were detected in all sediments, from both piston and boxed cores. The amounts determined ranged from $1.08 \%$ to $4.64 \%$. V. anguillarum was detected in none of the samples of CTD collected seawater or the sediments collected from boxed and piston cores. In addition, the CTD collected seawater was only hybridized by the universal 1392 probe.

\section{DISCUSSION}

Bacteria were classically identified based on phenotypical raits. Molecular identification based on the analysis of small subunit rDNA sequences would be more precise and reliable. Boivin-Jahns et al. (1995) have compared phenotypical and molecular methods for the identification of 74 bacterial strains which were isolated from a deep subsurface environment-a mine gallery. It was concluded that occurrences of misidentification were reduced by using molecular methods. This result will convince the most investigators in studies of microbial communities that the data collected by utilizing molecular method instead of the conventional cultural method is acceptable. In fact, the molecular method was proven useful in studying microorganisms present in deep-sea hydrothermal vents (Harmsen et al. 1997), and was used in ODP research (Taylor et al. 2000). Thus, bacteria hybridized by each specific probe in this study would reflect the realistic condition of each microorganism present in the examined sediments of the sea bottom.

It has been reported that marine waters contain mostly Archaea and sulfate-reducing bacteria. As the sampling area was reminiscent of a volcano, reduced forms of chemicals and elements were enriched in the anoxic environments which favor the growth of anaerobic bacteria such as sulfate-reducing bacteria and Archaea. Oligonucleotides SRB 804 (Devereux et al. 1992) and ARC 915 (Amann et al. 1990, 1995) were used to quantify the abundance of microbial life in the area investigated. As expected, sulfate-reducing bacteria and Archaea were the two predominant groups present in the sediments collected from the SPOT.

The drilling techniques used in OR586 were generally carried out by directly dropping the cores under gravity into the sea bottom to collect the sediments for geological formation studies. As contamination from equipment and drilling fluids was possible, care was needed. Therefore, recovered drilled-cores have to be split aseptically to retrieve uncontaminated sediments within. In addition, a tracer should be employed to indicate that the sample was uncontaminated. $V$. anguillarum is a gram-negative motile rod with fermentative and respiratory metabolism. It was commonly isolated from marine and estuarine fish (Bullock 1987) but its isolation from an extreme environment, such as deep-sea sediment 1000-meters below sea 
level, has never been reported. A specific oligonucleotide probe complementary to $16 \mathrm{~S}$ rRNA of $V$. anguillarum (Martinez-Picado et al. 1994) was used in the identification of this species. Therefore, this species was chosen as a microbial tracer to determine whether the collected sediments were contaminated by drilling fluids at the time of lifting the cores upward to the sea surface. As shown in Table 3, none of $V$. anguillarum could be detected by the $\mathrm{VaV} 3$ probe, suggesting there was no contamination of the examined samples. However, it is possible that the sparsity of $V$. anguillarum were present in the survey environments but escape the hybridization by VaV3 probe. According to the zero "tracer" results, the MPN vallue enumerated from the deep seawater samples and the sediments from boxed and piston core collection would be acceptable.

Jannasch and Mottl (1985) have demonstrated the inorganic chemical processes occurring at warm- and hot-water vent sites. In general, the hot anoxic hydrothermal fluid from volcanoes, containing geothermally reduced $\mathrm{H}_{2} \mathrm{~S}, \mathrm{~S}^{0}, \mathrm{H}_{2}, \mathrm{NH}_{4}^{+}, \mathrm{NO}_{2}{ }^{-}, \mathrm{Fe}^{2+}$ and $\mathrm{Mn}^{2+}$, as well as some $\mathrm{CH}_{4}$ and $\mathrm{CO}$, moves upward and will quickly be cooled by the colder seawater. The low concentration of dissolved oxygen due to a lack of photosynthesis by organisms results in the extremely anoxic environment on the sea bottom. Therefore, the dominant organisms in such an anoxic environment will be anaerobic reducing bacteria. Sulfate-reducing bacteria and Archaea (Fischer et al. 1983; Stetter and Gaag 1983) would be expected as dominant species, as previously studied.

Any slight presence of oxygen brought by a hydrothermal vent into an extremely anoxic environment would allow oxidizing microorganisms to utilize reduced-form elements as an electron donor for oxidation. In this condition, microorganisms that processing oxidation of $\mathrm{H}_{2}, \mathrm{CO}, \mathrm{NH}_{4}{ }^{+}, \mathrm{NO}_{2}^{-}, \mathrm{Fe}^{2+}$, and $\mathrm{Mn}^{2+}$ are assumed to contribute to chemoautotrophic production. As the redox potential favors reducing microorganisms in such anaerobic deep-sea environments, anaerobic oxidizers, if present, would be too few to be counted. However, if a small amount of dissolved oxygen were brought by a hydrothermal vent into this anoxic environment, the reduced elements would be utilized by oxidizing microorganisms, which would result in an increase in population size.

Straub et al. (1998) have isolated nitrate-dependent ferrous iron oxidizing strains BrG1, $\mathrm{BrG} 2$, and $\mathrm{BrG} 3$, and suggested that microorganisms can utilize ferrous iron anaerobically as an electron donor. In an anoxic sea-bottom environment, the state of redox potential would favor the nitrate reducing direction, i.e., $\mathrm{NO}_{3}{ }^{2-} \rightarrow \mathrm{NO}_{2}{ }^{-} \rightarrow \mathrm{NO} \rightarrow \mathrm{N}_{2} \mathrm{O} \rightarrow \mathrm{N}_{2}$. Tlkus, these nitrate-dependent ferrous iron oxidizers would be expected to be present in such an extremely anoxic environment, even if only in small amounts. If a small amount of dissolved oxygen were brought in, presumably by a hydrothermal vent, the amounts of ferrous iron oxidizers would increase. The oligonucleotide probe targeting these ferrous iron oxidizers would provide a convenient way to quantify the population size of ferrous iron oxidizers present in an anoxic sea bottom.

Suppose the eruption of volcano occurred under the sea bottom. The anoxic thermal fluids would rush upward to form black smokers, and would drift along with the courrent. The reduced ferrous iron would fall onto the area surrounding the volcano. Initially, cold onygenated seawater mixed with the anoxic hydrothermal fluids would be brought into this extremely anoxic environment under the sea bottom. This would favor the condition of oxidizing re- 
duced elements utilized by oxidizing microorganisms. This means, the population size of ferrous iron oxidizers would increase due to volcanic activity that results in hydrothermal vents bringing the oxygen into the area. The dissolved oxygen would be gradually be consumed and decrease since there is no oxygen input by photosynthesis. Therefore, ferrous iron oxidizers would adapt to the anoxic environment and the population size of oxidizers would decrease accordingly. In this study, the amounts of ferrous iron oxidizers which were hybridized by the BRG-I 829 probe were $1.08 \%$ to $4.64 \%$ of MPN counts. This low MPN count indicated that a homogenous anoxic environment was achieved and no dissolved oxygen was brought into this investigated area by hydrothermal vent. Therefore, it could be presumed that those volcanoes in the investigated SPOT area were in the state of dormant.

In most samples, less than $50 \%$ of bacteria were determined by the use of the designated specific probes. The situation of abundant of unknown microorganisms that could not be determined what they are was due to the lack of molecular signature of them. The diversity of microorganisms from any sampling sites was relatively low, showing the strong selectivity of prevailing conditions.

Microbial world of the deep-sea volcano located in area of SPOT was first time to be investigated by ODP group of Taiwan. Current issues in understanding of the deep subsurface biosphere were initiated by the use of $16 \mathrm{~S}$ rRNA oligonucleotides probe to target the selected bacteria. The established technique would be extended to future studies in the area of SPOT. Chemicals such as $\mathrm{H}_{2} \mathrm{~S}, \mathrm{~S}^{0}, \mathrm{H}_{2}, \mathrm{NH}_{4}^{+}, \mathrm{NO}_{2}^{-}, \mathrm{Fe}^{2+}$, and $\mathrm{Mn}^{2+}$, as well as some $\mathrm{CH}_{4}$ and $\mathrm{CO}$ in the environments would be analyzed in the future to help the interpretation of the data.

Acknowledgements We appreciate the help from the crew of Ocean Researcher I and their facilities for the drilling and coring works.

\section{REFERENCES}

Alm, E. W., D. B. Oerther, N. Larsen, D. A. Stahl, and L. Raskin, 1996: The oligonucleotide probe database. Appl. Environ. Microbiol., 62, 3557-3559.

Amann, R. I., L. Krumholz, and D. A. Stahl, 1990: Fluorescent-oligonucleotide probing of whole cells for determinative, phylogenetic, and environmental studies in microbiology. J. Bacteriol., 172, 762-77.

Amann, R. I., W. Ludwig, and K. H. Schleifer, 1995: Phylogenetic identification and in situ detection of individual microbial cells without cultivation. Microbiological Reviews, 59, 143-169.

Amann, R. I., W. Ludwig, and K. H. Schleifer, 1994: Identification of uncultured bacteria: a challenging task for molecular taxonomists. ASM News, 60, 360-365.

Atlas, R. M., and R. Bartha, 1998: Microbial Ecology: fundamentals and applications. Ch.9. 4th ed. Benjamin/Cummings Publishing Company, Inc., an imprint of Addison Wesley Longman, Inc.

Atlas, R. M., G. Sayler, R. S. Burlage, and A. K. Bej, 1992: Molecular approaches for environmental monitoring of microorganisms. BioTechniques, 12, 706-718.

Baranov, P. V., A. V. Kubarenko, O. L. Gurvich, T. A. Shamolina, and R. Brimacombe, 
1999: The database of ribosomal cross-links: an update. Nucleic Acids Research, 27, 184-185.

Boivin-Jahns, V., A. Bianchi, R. Ruimy, J. Garcin, S. Daumas, and R. Christen, 1995: Comparison of phenotypical and molecular methods for the identification of bacterial strains isolated from a deep subsurface environment. Appl. Envrion. Microbiol., 61, 34003406.

Bullock, G. L., 1987: Vibriosis in fish. Fish Dis. Leaflet, 77, 1-11.

Devereux, R., M. D. Kane, J. Winfrey, and D. A. Stahl, 1992: Genus- and group-specific hybridization probes for determinative and environmental studies of sulfate-reducing bacteria. Syst. Appl. Microbiol., 15, 601-609.

Dorsch, M., D. Lane, and E. Stackebrandt, 1992: Towards a phylogeny of the genus Vibrio based on 16S rRNA sequences. Int. J. Syst. Bacteriol., 42, 58-63.

Fischer, F., W. Zillig, K. O. Stetter, and G. Schreiber, 1983: Chemolithoautotrophic metabolism of anaerobic extremely thermophilic archaebacteria. Nature (London), 301, 511513.

Harmsen, H. J. M., D. Prieur, and C. Jeanthon, 1997: Distribution of microorganisms in deepsea hydrothermal vent chimneys investigated by whole-cell hybridization and enrichment culture of thermophilic subpopulations. Appl. Environ. Microbiol., 63, 2876-2883.

Hobbie, J. E., R. J. Daley, and S. Jasper, 1977: Use of nucleopore filters for counting bacteria by fluorescence microscopy. Appl. Environ. Microbiol., 33, 1225-1228.

Holben, W. E., J. K. Jansson, B. K. Chelm, and J. M. Tiedje, 1988: DNA probe method for the detection of specific microorganisms in the soil bacterial community. Appl. Environ. Microbiol., 61, 703-711.

Holben, W. W., and J. M. Tiedje, 1988: Applications of nucleic acid hybridization in microbial ecology. Ecology, 69, 561-568.

Jannasch, H. W., and M. J. Mottl, 1985: Geomicrobiology of deep-sea hydrothermal vents. Science, 229, 717-725.

Karl, D. M., C. O. Wirsen, and H. W. Jannasch, 1980: Deep-sea primary production at the Galapagos hydrothermal vents. Science, 207, 1345-1347.

Maidak, B. L., J. R. Cole, C. T. Parker, Jr, G. M. Garrity, N. Larsen, B. Li, T. G. Lilburn, M. J. McCaughey, G. J. Olsen, R. Overbeek, S. Pramanik, T. M. Schmidt, J. M. Tiedje, and C. R. Woese, 1999: A new version of the RDP (ribosomal database project). Nucleic Acids Research, 27, 171-173.

Maidak, B. L., G. J. Olsen, N. Larsen, R. Overbeek, M. J. McCaughey, and C. R. Woese, 1996: The ribosomal database project (RDP). Nucleic Acids Research, 24, 82-85.

Martinez-Picado, J., A. R. Blanch, and J. Jofre, 1994: Rapid detection and identification of Vibrio anguillarum by using a specific oligonucleotide probe complementary to $16 \mathrm{~S}$ rRNA. Appl. Environ. Microbiol., 60, 732-737.

Moran, M. A., V. L. Torsvik, T. Torsvik, and R. E. Hodson, 1993: Direct extraction and purification of rRNA for ecological studies. Appl. Environ. Microbiol., 59, 915-918.

Olsen, G. J., D. J. Lane, S. J. Giovannoni, N. R. Pace, and D. A. Stahl, 1986: Microbial ecology and evolution: a ribosomal RNA approach. Annu. Rev. Microbiol., 40, 337365. 
Pace N. R., 1996: New perspective on the natural microbial world: molecular microbial ecology, ASM News, 62, 463-470.

Polz, M. F., and C. M. Cavanaugh, 1997: A simple method for quantification of uncultured microorganisms in the environment based on in vitro transcription of $16 \mathrm{~S}$ rRNA. Appl. Environ. Microbiol., 63, 1028-1033.

Purdy, K. J., T. M. Embley, S. Takh, and D. B. Nedwell, 1996: Rapid extraction of DNA and rRNA from sediments by a novel hydroxyapatite spin-column method. Appl. Environ. Microbiol., 62, 3905-3907.

Sayler, G. S., and A. C. Layton, 1990: Environmental application of nucleic acid hybridization. Annu. Rev. Microbiol., 44, 625-648.

Sambrook J, E. F. Frisch, and T. Maniatis, 1989: Molecular cloning: a laboratory manual, $2^{\text {nd }}$ edn. Cold Spring Harbor Laboratory Press. Cold Spring Harbor, New York.

Stahl, D. A., 1993: The natural history of microorganisms. ASM News, 59, 609-613.

Stahl, D. A., B. Flesher, H. R. Mansfield, and L. Montgomery, 1988: Use of phylogenetically based hybridization probes for studies of ruminal microbial ecology. Appl. Environ. Microbiol., 54, 1079-1084.

Stetter, K. O., 1995: Microbial life in hyperthermal environments. ASM News, 61, 285-290.

Stetter, K. O., and G. Gaag, 1983: Reduction of molecular sulphur by methanogenic bacteria. Nature (London), 305, 301-310.

Straub, K. L., and B. E. E. Buchholz-Cleven, 1998: Enumeration and detection of anaerobic ferrous iron-oxidizing, nitrate-reducing bacteria from diverse European sediments. Appl. Environ. Microbiol., 64, 4846-4856.

Taylor, B., P. Huchon, A. Klaus, and the Leg 180 Scientific Party, 2000: Continental rifting, low-angle normal faulting and deep biosphere: results of Leg 180 drilling in the Woodlark Basin. JOIDES J., 25, 4-7.

Ward, D. M., M. M. Bateson, R. Weller, and A. L. Ruff-Roberts, 1992: Ribosomal RNA analysis of microorganisms as they occur in nature. Adv. Microb. Ecol., 12, 219-286.

Woese, C. R., R. Gutell, R. Gupta, and H. F. Noller, 1983: Detailed analysis of the higherorder structure of 16S-like ribosomal ribonucleic acids. Microbiology Reviews, 47, 621669. 